\title{
FORAMINIFERAL RECORD OF ENVIRONMENTAL CHANGES: PRE- EVAPORITIC DIATOMACEOUS SEDIMENTS FROM GAVDOS ISLAND, SOUTHERN GREECE.
}

\author{
Drinia H., Antonarakou A., Tsaparas N., Dermitzakis M.D. and Kontakiotis G. \\ National and Kapodistrian University of Athens, Dept. Of Geology, Section of Hist. Geology- \\ Paleontology, Panepistimiopolis, 157-84 Athens, Greece, cntrinia@geol.uoa.gr, \\ aantonar@geol.uoa.gr,ntsapar@geol.uoa.gr,mderm@geol.uoa.gr, gkontak@geol.uoa.gr
}

\begin{abstract}
The Messinian pre-evaporitic sedimentary succession of Gavdos island (Metochia section) is a nearly uninterrupted succession of marine sediments, dominated by finely laminated diatomaceous sediments, which are cyclically alternating with marlstone and white limestone beds. The purpose of this study is to analyze in detail the benthic and planktonic foraminiferal microfauna preserved in the sediments of this section. The qualitative and quantitative analysis of the planktonic foraminifera fauna allowed the recognition of seven bioevents, which have been astronomically dated for the Mediterranean. The base of the diatomitic succession in Gavdos Island is dated at $6.696 \mathrm{Myr}$, whereas its top at $6.0 \mathrm{Myr}$. Our results suggest that two environmental parameters are the most important factors that control the community structure of the benthic foraminiferal fauna: the food availability and oxygen concentration. In addition, local upwelling phenomena evidenced by signals from the benthic foraminifera and the distribution pattern of the planktonic G. bulloides may have played a role in the faunal density and composition.
\end{abstract}

\section{INTRODUCTION}

Messinian evaporites in the deep Mediterranean basins and Messinian "salinity crisis" (MSC) have been the subject of several studies and speculations. Restricted environmental conditions in the Mediterranean were the main cause of the widespread deposition of evaporites. The preevaporitic sediments are characterized by predominantly alternations of marl/sapropel sequences (Late Tortonian to early Messinian), which pass to either diatomites (e.g. Sicily, northeastern Morocco, Algeria) or euxinic clays (e.g. northern Italy, Tyrrhenian Sea, eastern Mediterranean). Paleoenvironmental changes related to these lithological transitions are documented by faunal (e.g. Cita, 1976; Glacon et al., 1990; Benson \& Rakic-El Bied, 1991; Benson et al., 1991; Sierro et al., 1993; Hodell et al., 1994) and geochemical (stable isotope) parameters (e.g. Vergnaud-Grazzini, 1983; Hodell et al., 1994; Ferretti \& Terzi, 1995). The increasing accuracy of time control (Hilgen et al., 1995; Shackleton et al., 1995) improves the correlation of these phenomena throughout the Mediterranean.

The purpose of this study is to reconstruct the paleoenviromental trends and events leading to the MSC during the transition from the Tortonian open marine conditions to the Messinian evaporitic environments, in the Eastern Mediterranean basin. The succession of paleoenvironments and foraminifera assemblages is analyzed from the time period before the Messinian evaporitic deposition in Metochia section, Gavdos Island.

\section{MATERIAL AND METHODS}

\subsection{Study area}

Metochia section (NE Gavdos Island, Fig. 1), is a Late Miocene hemipelagic marl succession characterized by the rhythmic alternations of poorly non-bioturbated brown-grey, organic rich lami- 
nated beds (sapropels) and bioturbated, light grey-blue, homogeneous, hemipelagic marl beds. The thickness of successive sapropel and marl beds varies such that distinct small and large scale clusters can be distinguished. The upper part of this sequence is composed of 14 meters of diatomite deposits. This part consists of alternations of diatomite beds with white limestone beds, clay diatomites, diatomaceous marls and grey thin-bedded limestone (Triantaphyllou et al., 1999) (Fig. 1). Hilgen et al., (1995) have counted 38 sedimentary cycles in these deposits and dated the base of the diatomite sequence at 6.696 Ma. Perez-Folgado et al. (2003) described the lower part (6.606$6.5 \mathrm{Ma}$ ) of the sedimentary cycles of the diatomite sequence as typically tripartite, composed of light-brown marls (sapropel-like), a thick diatomite and an homogenous marl.

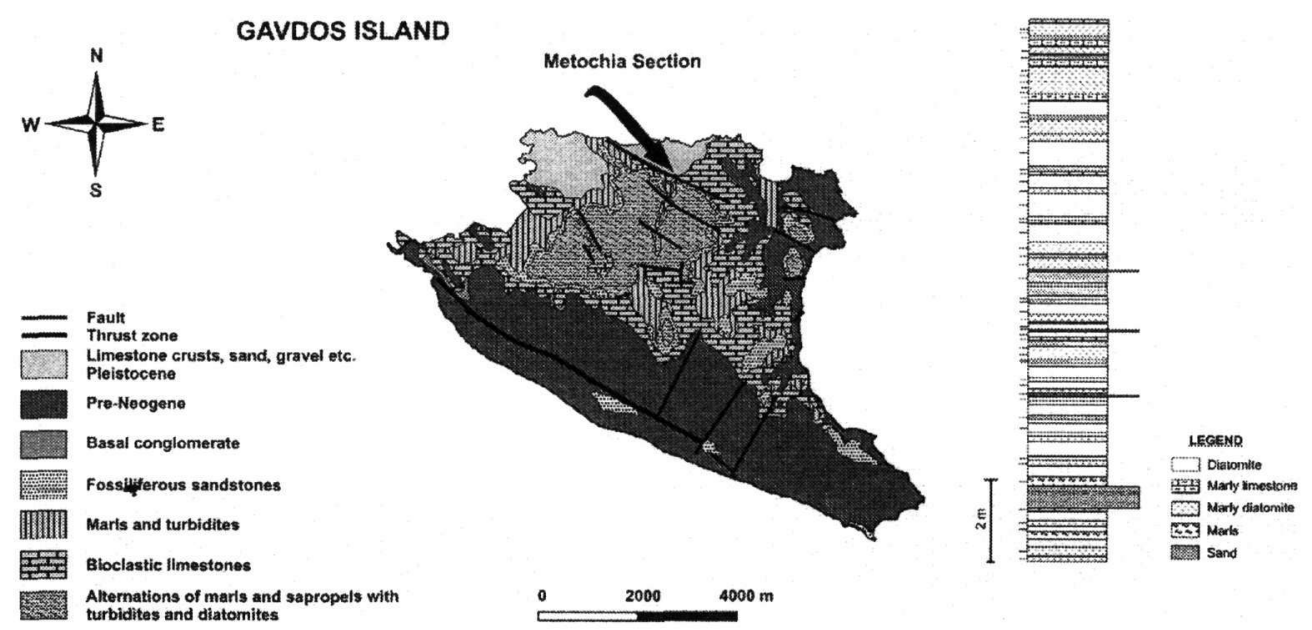

Fig. 1. Location map and lithostratigraphical column of the upper part of the Metochia Section.

\subsection{Micropaleontological analysis}

40 samples from the diatomite sequence of Metochia section were collected. After washing and drying, samples were sieved through 125 and $63 \mu \mathrm{m}$ mesh. From the $>125 \mu \mathrm{m}$ size fraction $300-$ 500 individuals of foraminifera were randomly picked. Quantitative and qualitative analysis of the benthic and planktonic foraminifera was performed in almost all the samples.

On the basis of the faunal counts, values $\mathrm{H}(\mathrm{s})$ for diversity using the Shannon-Wiener information equation (Buzas \& Gibson, 1969), Species Richness (number of species), Equitability (Buzas \& Gibson 1969), Dominanse and the Fischer $\alpha$-index (Fisher et al. 1943), were calculated. Raw data of microfossils were then transformed into percentages over the total abundance and percentage abundance curves were plotted. Species with phylogenetic affinities and similar environmental significance were also grouped to better interpret distribution patterns. Additionally, Planktonic/Benthic $(P / B)$ ratios expressed as $100^{\star} P /(P+B)$, i.e. the percentages of planktonic foraminifera in the total foraminiferal assemblages, and infauna versus epifauna are used as indicators of paleobathymetry, paleoproductivity and upwelling. Paleobathymetry was also calculated for each sample by introducing P/B ratios, based on epifaunal species, in the equation of v.d. Zwaan et al. (1990).

\section{PLANKTONIC FORAMINIFERAL BIOSTRATIGRAPHY}

The quantitative distribution patterns of the most representative planktonic foraminiferal taxa are summarized in Fig.2. A quantitative biostratigraphic analysis of the planktonic fotraminifera was carried out in order to pinpoint accurately the position of bio-events (Table 1).

In the lower part of the section the first abundant occurrence of Globigerina obesa has been recognized at around $3 \mathrm{~m}$ of the section, dated at $6.610 \mathrm{Ma}$ (Krijgsman et al., 1999). This species 
occurs almost continuously in our record. Intervals characterized by its absence or low abundances are recorded in the diatomaceous layers.

Table 1: Planktonic foraminifera bioevents in the upper part of the Metochia Section (Krijgsman et al., 1999)

\begin{tabular}{|l|c|c|}
\hline \multicolumn{1}{|c|}{ Planktonic Foraminifera events } & $\begin{array}{c}\text { Stratigraphical } \\
\text { level }(\mathbf{m})\end{array}$ & Age (Myr) \\
\hline (1) Globigerina obesa FAO & 3,40 & 6.610 \\
\hline (2) Globorotalia conomiozea LO & 5,70 & 6.500 \\
\hline (3) Turborotalita multiloba FAO & 7,00 & 6.415 \\
\hline (4) Neogloboquadrina acostaensis d/s & 8,50 & 6.337 \\
\hline (5) N. acostaensis dominance sin. forms & 12,70 & 6.108 \\
\hline (6) N. acostaensis influx sinistral & 14,20 & 6.099 \\
\hline (7) Globorotalia scitula influx & 14,60 & 6.082 \\
\hline
\end{tabular}

The second significant biostratigraphic event is the last occurrence of Globorotalia miotumida group which has been dated at $6.552 \mathrm{Ma}$ (Krijgsman et al., 1995). This event is followed by two distinct influxes of the group. One is recorded around $5,7 \mathrm{~m}$ and the second, which is less prominent, at around $3,5 \mathrm{~m}$ of the section. Sierro et al. (2001), recognized also two influxes of $\mathrm{G}$. miotumida group in Sorbas, dated at 6.552 and 6.585 Ma. In Gavdos diatomites, Perez-Folgado et al. (2003), who worked in the lower part of the section, identified only the older influx of the group on top of the diatomite cycle which lithologicaly corresponds to our record.

The entry of Turborotalita multiloba is a very usefull bioevent and has been widely used for biostratigraphic correlations inside the Mediterranean. This event has been astronomically dated at 6.415 Ma (Krijgsman et al., 1999; Hilgen \& Krijgsman, 1999). Short incursions of the species are recorded in our record before its regular occurrence in the section.

The distribution and coiling pattern of Globorotalia scitula group which comprises all the unkeeled globorotaliids (G. scitula, G. nicolae, G. ventriosa) of our data, are used for biostratigraphic correlation throughout the Messinian, inside and outside the Mediterranean (Krijgsman et al., 1995; Sierro et al., 1993; 2001). In our record, this group is abundant in the lower part of the section with preferentially dextral coiling and then the group shows prominent incursions and frequent shifts in coiling direction, from sinistral to dextral and vice versa, up to the top of the section. In the Mediterranean the two last influxes of $G$. scitula group have been astronomically dated (Krijgsman et al., 1999). In Gavdos diatomites, the last distinct influx of this group has been identified just above the last sinistrally coiling Neogloboquadrina acostaensis influx, (at $14.6 \mathrm{~m}$ ), dated at 6.082 .

Neogloboquadrina acostaensis is very abundant in our record reaching high abundances in the upper part, in diatomaceous marls and in the thick diatomite beds. Dextral and sinistral specimens were counted separately, in order to define a better biostratigraphic framework for the studied section. In the lower part, coiling is dominantly sinistral. A very prominent coiling change from sinistral to dextral is reported at $8,5 \mathrm{~m}$ which is correlated to the astronomically date of $6,337 \mathrm{ma}$ (Krijgsman et al., 1999). This event has been recognized both in the Mediterranean (Sierro et al., 1993; Sprovieri et al. 1996; and others) and Atlantic regions (Sierro et al., 1993; Benson et al., 1991 and others). laccarino (1985) used this event to define the base of the Non- distinctive Zone in the Messinian in the Mediterranean.

Moreover, two distict events into the distribution pattern of Neogloboquadrina acostaensis were recognized, one is recorded at $12,7 \mathrm{~m}$ where sinistrally coiled specimens are dominant, dated at $6,108 \mathrm{Ma}$, and the other at 14,20 m, dated at 6.099 Ma (Hilgen \& Krijgsman, 1999) referred to the significant influx of sinistral forms.

All these events described above indicate that the studied interval ranges from $6.7 \mathrm{Ma}$ as it is recorded from the onset of the diatomite sequence for Gavdos island, to $6.082 \mathrm{Ma}$ according to the last influx of Globorotalia scitula group. 


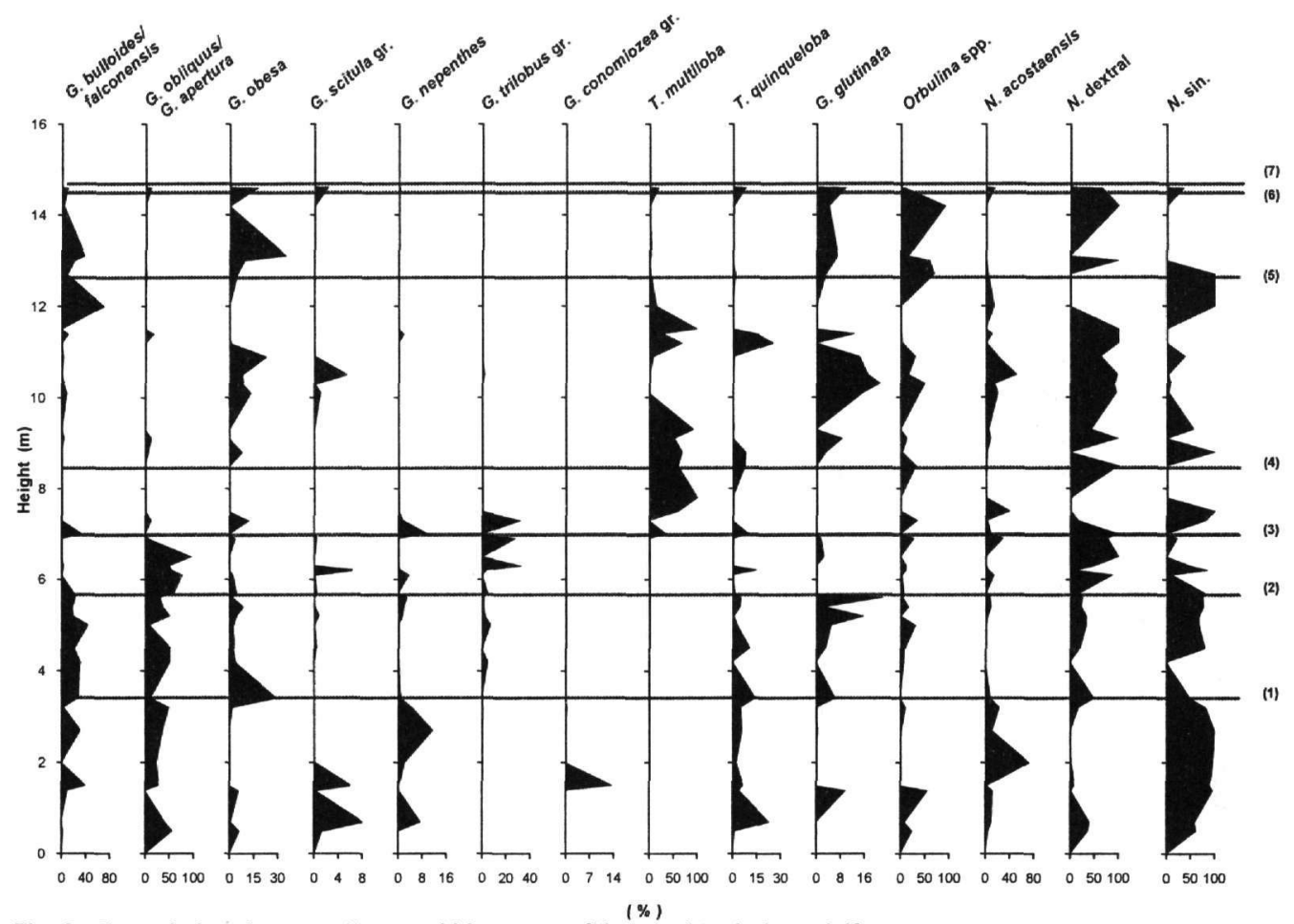

Fig. 2. Faunal abundance pattern and bioevents of the planktonic foraminifera.

\section{THE BENTHIC FORAMINIFERAL RECORD}

\subsection{Faunal pattern}

The distribution of dominant, common or significant species, which characterize the benthic foraminiferal fauna of Metochia Section, is reported in Fig.3.

The most representative species of the diverse benthic foraminiferal fauna are: Bolivina plicatella, Bolivina spathulata group (B. spathulata, B. dilatata, B. tortuosa), Bulimina aculeata group (B. aculeata, B. elongata, B. lappa), Elphidium sp, Asterigerinata planorbis and Gyroidinoides neosoldanii. Additional and significant species are Anomalinoides sp., Cibicidoides kullenbergi, $C$. ungerianus, Cibicides lobatulus, Cassidulina laevigata, Melonis padanum, Uvigerina sp., Valvulineria bradyana and G/cbocassidulina oblongus.

Bolivinidae and Buliminidae dominate throughout the succession, strongly fluctuating in the range of $0,5-79 \%$ and $1-98 \%$ respectively. Among the Bolivinidae, B. plicatella and $B$. spathulata group, are the most common. Bolivina plicatella is relatively abundant in the basal part of the section, displaying peak occurrences at $0,5 \mathrm{~m}$ and $4,2 \mathrm{~m}(76,5 \%$ and $64,6 \%$ respectively). On the contrary, B. spathulata group is abundant in the middle and upper part of the section, displaying its highest percent value at $8,5 \mathrm{~m}(49,29 \%)$. Bulimina aculeata group shows its highest frequency at 2 $\mathrm{m}(98 \%)$.

Asterigerinata planorbis and Elphidium sp. occur from the base to the top of the section with their highest frequencies in the middle of the succession, at 6,9 and $7,3 \mathrm{~m} \mathrm{(46 \%}$ and $78 \%$ respectively).

From the faunal pattern of benthic foraminifera, the species Bolivina plicatella, Hanzawaia boueana, Cibicidoides kullenbergi, Melonis padanum, Cassidulina laevigata, Valvulineria bradyana, Globocassidulina oblongus display a decreasing trend, whereas Anomalinoides sp., Cibicidoides ungerianus, Bolivina spathulata and Uvigerina sp. show an increasing trend, up to the top of the section. 


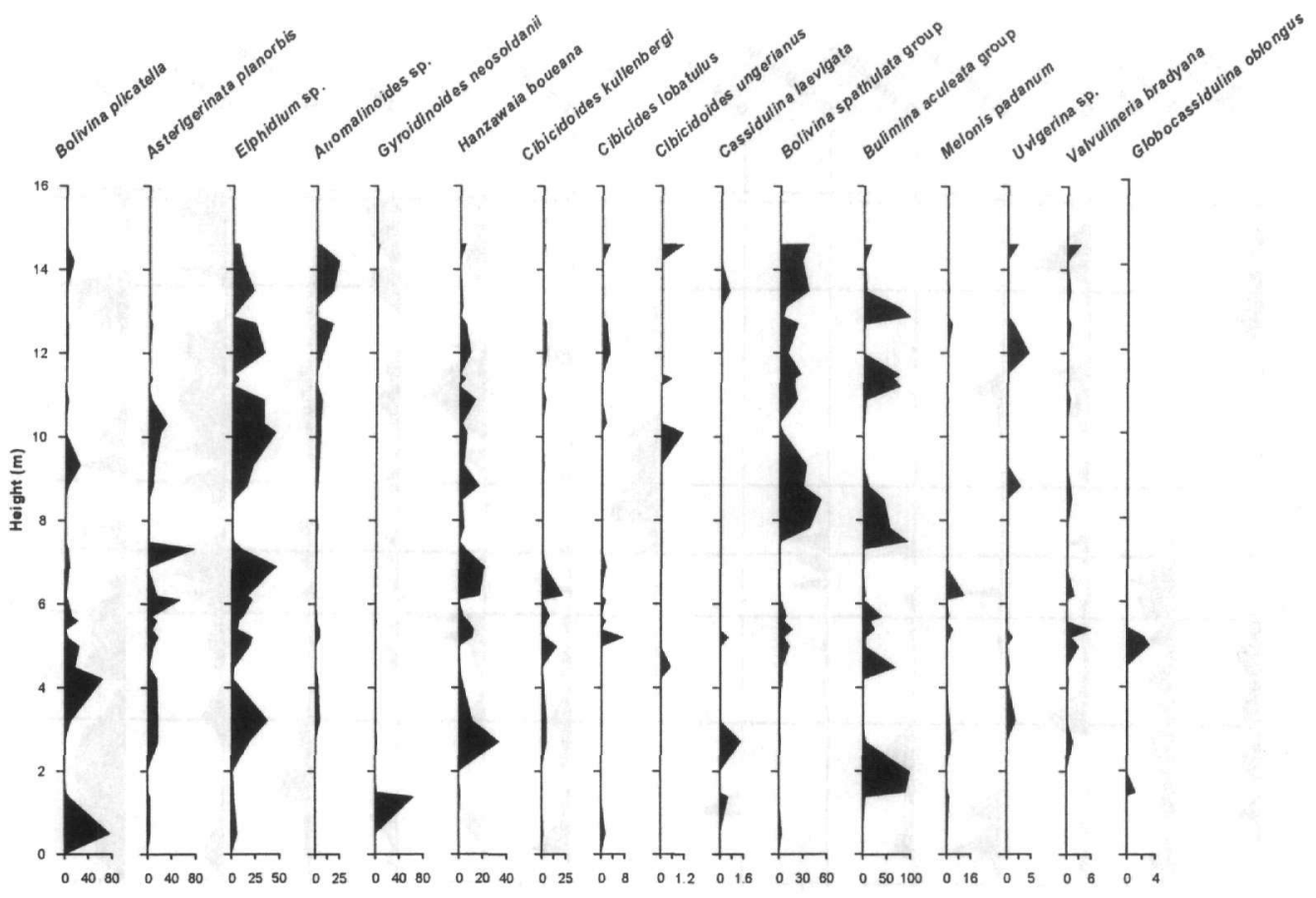

(\%)

Fig. 3. Faunal abundance pattern of benthic foraminifera.

\subsection{Diversity}

Diversity indices expressed by Shannon diversity $(H(s))$, Fischer alpha, Equitability and Dominance have been measured for each sample collected from Metochia Section and are shown in Table 2. These indices are in accordance with the faunal abundance pattern implying that high diversity corresponds with low dominance and low equitability.

Table 2: Benthic foraminiferal faunal parameters.

\begin{tabular}{|c|c|c|c|c|c|}
\hline Height & Taxa & Dominance & Shannon index & Equitability & Fisher- $\alpha$ \\
\hline 0,5 & 18 & 76,50 & 0,97 & 0,39 & 3,56 \\
\hline $\mathbf{1 , 4}$ & 11 & 68,18 & 1,09 & 0,53 & 2,08 \\
\hline $\mathbf{1 , 5}$ & 8 & 88,75 & 0,56 & 0,27 & 2,06 \\
\hline $\mathbf{2 , 0}$ & 4 & 98,03 & 0,11 & 0,08 & 0,84 \\
\hline $\mathbf{2 , 7}$ & 13 & 34,78 & 1,75 & 0,80 & 2,44 \\
\hline 3,2 & 14 & 28,57 & 1,74 & 0,79 & 2,46 \\
\hline $\mathbf{4 , 2}$ & 13 & 67,51 & 1,16 & 0,48 & 3,12 \\
\hline $\mathbf{4 , 5}$ & 13 & 67,94 & 1,02 & 0,49 & 2,07 \\
\hline $\mathbf{5 , 0}$ & 11 & 24,24 & 2,05 & 0,89 & 2,81 \\
\hline $\mathbf{5 , 2}$ & 33 & 16,37 & 2,28 & 0,86 & 4,58 \\
\hline 5,4 & 18 & 25,49 & 2,16 & 0,87 & 3,67 \\
\hline 5,6 & 22 & 24,10 & 2,15 & 0,84 & 4,15 \\
\hline 5,7 & 14 & 40,85 & 1,78 & 0,81 & 2,45 \\
\hline 6,1 & 9 & 63,64 & 1,05 & 0,54 & 1,70 \\
\hline 6,2 & 12 & 22,03 & 2,01 & 0,87 & 2,79 \\
\hline 6,9 & 9 & 32,91 & 1,34 & 0,75 & 1,40 \\
\hline 7,3 & 5 & 78,08 & 0,81 & 0,50 & 1,11 \\
\hline 7,5 & 10 & 92,27 & 0,38 & 0,18 & 2,07 \\
\hline
\end{tabular}

\begin{tabular}{|c|c|c|c|c|c|}
\hline Height & Taxa & Dominance & Shannon index & Equitability & Fisher- $\alpha$ \\
\hline $\mathbf{7 , 8}$ & $\mathbf{7}$ & 54,64 & 0,90 & 0,56 & 1,11 \\
\hline $\mathbf{8 , 5}$ & $\mathbf{5}$ & 49,29 & 0,89 & 0,50 & 1,40 \\
\hline $\mathbf{8 , 8}$ & 13 & 28,00 & 1,73 & 0,83 & 2,11 \\
\hline $\mathbf{9 , 3}$ & 10 & 24,00 & 1,68 & 0,81 & 2,05 \\
\hline 10,1 & 14 & 26,37 & 1,29 & 0,72 & 1,49 \\
\hline 10,3 & 14 & 29,73 & 1,52 & 0,78 & 1,74 \\
\hline 10,9 & 20 & 22,22 & 1,88 & 0,78 & 3,21 \\
\hline 11,2 & 7 & 77,78 & 0,65 & 0,36 & 1,41 \\
\hline 11,4 & 9 & 62,05 & 1,16 & 0,65 & 1,40 \\
\hline 11,5 & 4 & 73,26 & 0,63 & 0,57 & 0,58 \\
\hline 12,0 & 18 & 31,34 & 1,96 & 0,82 & 3,47 \\
\hline 12,7 & 24 & 22,97 & 2,10 & 0,80 & 4,60 \\
\hline 12,9 & 3 & 95,45 & 0,21 & 0,19 & 0,58 \\
\hline 13,1 & 11 & 75,24 & 0,86 & 0,48 & 1,41 \\
\hline 13,5 & 18 & 34,66 & 1,54 & 0,67 & 2,90 \\
\hline 14,2 & 11 & 23,46 & 1,66 & 0,86 & 1,83 \\
\hline 14,6 & 22 & 30,43 & 1,94 & 0,78 & 3,79 \\
\hline
\end{tabular}

Low values of Fischer- $\alpha$ index (at 2, 11,5 and 12,9 $\mathrm{m}$ of the record) suggest some deviation from the norm of the paleoenvironmental parameters (Jorissen, 1987; v. d. Zwaan \& Jorissen, 1991). In addition, the availability of strong dominance of some species (at 1,5, 2, 7,5 and 12,9 m) in relation with low species diversity suggests conditions of environmental stress.

An abrupt decrease of diversity, tugged by an increase in dominance, at $4,5 \mathrm{~m}, 7,5 \mathrm{~m}, 11,2 \mathrm{~m}$ and $11,5 \mathrm{~m}$ of the record, is discerned. This is may due to the peak occurrence of the infaunal $\mathrm{Bu}$ - 
limina aculeata group, which is high tolerant to raised salinities and oxygen deficiencies ( $v$. d. Zwaan, 1982; Jonkers, 1984; Verhallen, 1991; Rohling et al., 1993). The same stands for the interval at $12,9 \mathrm{~m}$, where peak occurrence of Bolivina spathulata group indicates high organic content and dysoxia (v. d. Zwaan, 1982; Jonkers, 1984; Katz \& Thunell, 1984; Sprovieri et al., 1986; SenGupta et al., 1989, Murray, 1991, Verhallen, 1991, Jorissen et al., 1992; Kaiho, 1994; Loubère, 1996, 1997, Kouwenhoven et al., 1999). On the contrary, in the middle or the basal part of the succession, the appearance of the epiphytic group, which constitutes up to $50 \%$ of the benthic assemblage and is represented by preferentially photofile forms (as Elphidium spp. and Asterigerinata planorbis) implies more stable environmental conditions.

\subsection{Infauna-Epifauna}

The benthic assemblages have been divided into two major ecological categories, epifaunashallow infauna and deep infauna, based on habitat preferences known for their recent representatives (Jorissen et al., 1995). A plot of their relative abundances (Fig.4) shows the epifaunal component dominating the benthic community in total numbers, except of five intervals (at about $2 \mathrm{~m}, 4,5$ $m, 8 m, 11,5 \mathrm{~m}$ and $13 \mathrm{~m}$ ), where the infaunal component rises more significantly.

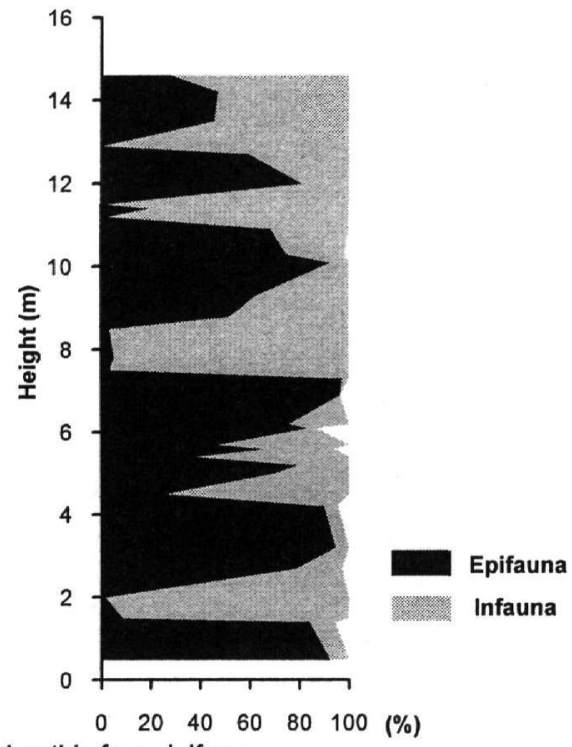

Fig. 4. Infauna versus Epifauna benthic foraminifera

Dominance of the epifaunal group indicates well-ventillated bottom water environments and a rather deep position of the redox front. Van der Zwaan et al. (1999) assume that these species are not so tolerant to oxygen stress, but very well able to compete for food. This explains their prominent position at the sediment-water interface under normal conditions. According to Jorissen et al. (1995) and v. d. Zwaan et al. (1999), with increasing water depth, nutrients become limitative. As a consequence of the limited amount of organic flux reaching deep environments, less organic matter is stored in the sediment, rendering the deeper sediment layers a less profitable environment for potential infaunal species. In addition the parallels between plankton and benthos are such that the warmer relatively oligotrophic planktonic group (Globoturborotalita aperture - Globigerinoides obliquus group) varies together with the epifaunal group (Fig. 2).

On the contrary, it is well documented that infaunal foraminifera prefer nutrient-rich, low oxygen, muddy environments and their high abundances usually signal eutrophication in the water column (Barmawidjaja et al. 1992, Verhallen 1991). These conditions are more typical of colder or deeper waters and may occur in shallower sites with upwelling influence. Other mechanisms, which may produce a similar effect, include large-scale runoff that produces a brackish water lid and ultimately a high nutrient level. 
In the first case, the upwelling suggests that cool and very productive waters characterized these parts of the section (at about $2 \mathrm{~m}, 4,5 \mathrm{~m}, 11,5 \mathrm{~m}$ and $13 \mathrm{~m}$ ). The upwelling is preceded by peaks in the frequency of Globigerina bulloides (Fig. 2) (a species better adapted to highproductivity upwelling regimes with fairly uniform properties). Upwelling cold currents may have favored the cooling and sinking of surface waters with the subsequent upward mixing of nutrient-rich intermediate waters (Rohling \& Bigg, 1998; Sierro et al., 2003). We, therefore, suggest the establishment in these parts of the section, of a small upwelling cell, probably as a result of wind strengthening. In the second case, at about $8 \mathrm{~m}$ height, the high abundance of infaunal species is associated with, perhaps, an enhanced river input. This is in accordance with a relatively decrease of $\mathrm{P} / \mathrm{B}$ ratio. Bolivina spathulata group and Bulimina aculeata group are the most abundant species in this interval, indicating the existence of oxygen-poor, organic-rich waters at the bottom and more restricted conditions.

\section{PALEOBATHYMETRY}

The approximate water depth for the sediments from the Metochia Section is assessed by introducing P/B ratios based on epifaunal species, in the equation of v. d. Zwaan et al. (1990).

Based on water depth zonation of Bremer et al. (1980) and van Morkhoven et al. (1986), the depositional depth of the Section varies from around 150 to $1200 \mathrm{~m}$ indicating an environment in the upper to lower bathyal zone (Fig.5a). According to v. d. Zwaan et al. (1990) the low values of depth might be due to low values of the P/B ratio (Fig. 5b) and probably represent benthic "bloom".

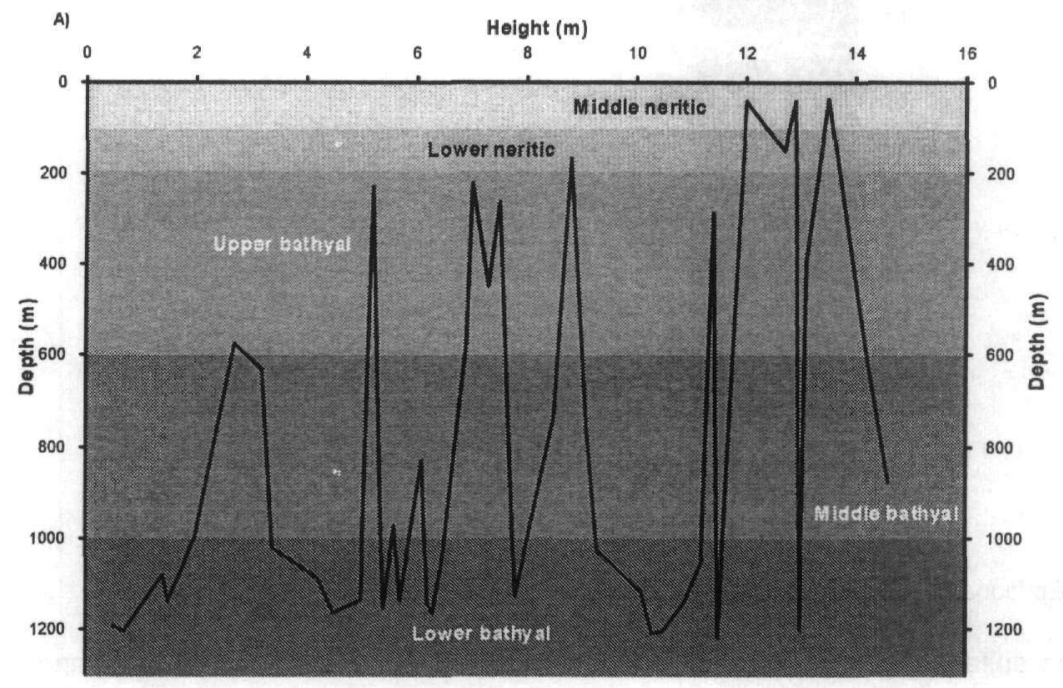

B) $\mathrm{P} /(\mathrm{P}+\mathrm{B}) 100$

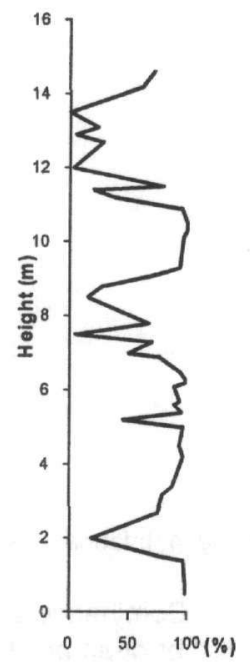

Fig. 5a. Paleodepth reconstruction. 5b. P/B ratio.

As the assemblages recorded from the Metochia section consist of species that are alive today, paleobathymetries have been also estimated through a direct comparison with water-depth ranges seen in their present-day counterparts. References we used include general studies (e.g. van Morkhoven et al., 1986; Murray, 1991) and a selection of papers concerning the Mediterranean Sea (e.g. Parker, 1958; Todd, 1957; Bandy \& Chierici, 1966; Venec-Peyre, 1984; Jorissen, 1987; Cimerman \& Langer, 1991). The depth-diagnostic benthic foraminifera taxa, selected among those having common or abundant occurrences in the Metochia Section are (Table 3): Bolivina spathulata group, Bulimina aculeata group, Melonis padanum, Bolivina plicatella, Asterigerinata planorbis, Elphidium sp., Anomalinoides sp., Gyroidinoides neosoldanii, Hanzawaia boueana and Cibicidoides kullenbergi. The depth range chart goes in accordance with the results extracted from the formula used for the calculation of the paleodepth, which means that the benthic foraminiferal assemblages are indicative of an upper to lower bathyal environment. 
Foraminiferal assemblage distribution has been used to reconstruct the paleoenvironmental conditions that prevailed during the deposition of the diatomaceous part of the Metochia Section in Gavdos Island. These deposits, based on biostratigraphic data, have been dated at 6,69-6,082 Ma and were deposited in an upper to lower bathyal environment, characterized by a high concentration of organic matter and a generally dominance of epifaunal versus infaunal species. The intervals that infaunal species dominate may be linked to fluvial discharge or local upwelling.

Table 3: Bathymetric significance of dominant and important associated species from the Metochia Section.

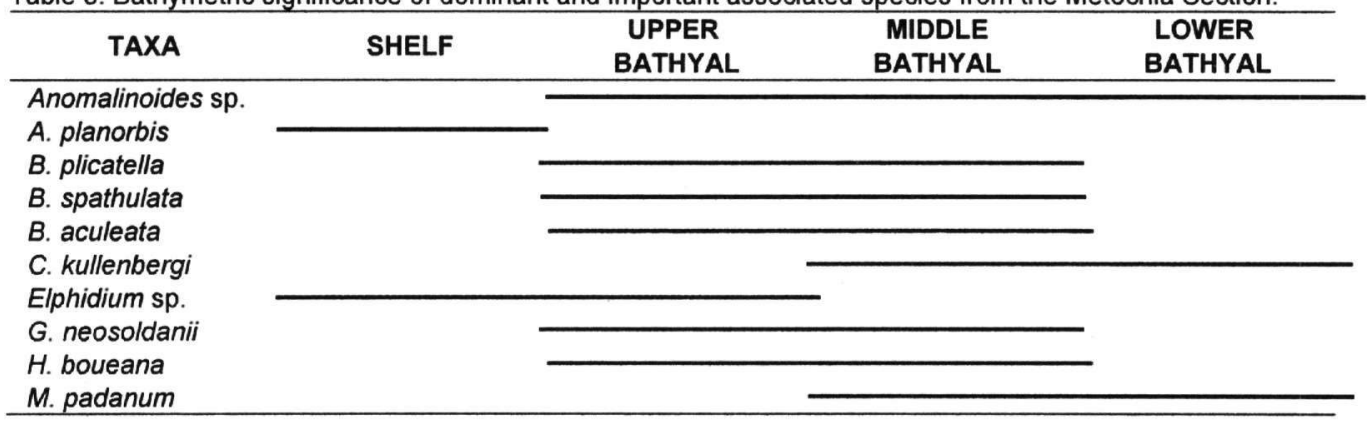

The basal part of the section (0-6 m) is characterized by the high percentage values of Bolivina plicatella, an indicative species of moderate paleoenvironmental stress. According to $v$. d. Zwaan (1982) Bolivina plicatella is highly tolerant to raised salinities and oxygen deficiencies, while $v$. d. Zwaan \& Hartog Jager (1983) consider it as an epiphytic species. According to Seidenkrantz et al. (2000), dominance of Bolivina plicatella is a result of an increased salinity. At 1,4 m, Gyroidinoides neosoldanii is the most dominant species. This species seems to be excellent marker of organic matter and doesn't tolerate strong ecological stress due to long periods of very low oxygen levels (Mullineaux \& Lohmann, 1981; de Stigter et al., 1998). High abundances of Elphidium sp. are suggestive of shallow water and probably indicative of an allochthonous fauna derived from a slump block of neritic origin (Brunner \& Culver, 1992). These increased percentage values may be due to the substrate, which seems to overpass to ecological stress. In the middle part of the section (8-10 $\mathrm{m}$ ), the paleoenvironmental conditions are characterized by intense stress due to low oxygen content. Bolivinidae and Buliminidae dominate to the total benthic foraminifera fauna. In the upper part of the section (10-14,6 m), Bolivina spathulata group shows its highest percent values and reveal that is found is the most favourable conditions. According to van der Zwaan (1982), Verhallen (1991), Jorissen et al. (1992), Kaiho (1994), Loubere (1996, 1997), Bolivina dilatata tends to increase when the influx of terrigenous organic matter dominates the environment. Generally, zones influenced by runoff products are dominated by species with a tolerance to stressed conditions (Jorissen, 1999). But according to Phleger \& Soutar (1973), Sen Gupta et al. (1989), Caralp (1989) and Gooday (1993), benthic assemblages dominated by Bolivina typify low oxygen environments with a sustained flux of organic matter in regions of high productivity, often associated with intense upwelling.

\section{REFERENCES}

Bandy, O.L., and Chierici, M.A., 1966. Depth temperature evaluation of selected Californian and Mediterranean bathyal foraminifera, Mar. Geology, 4, 259-271.

Barmawidiaja, D.M., Jorissen, F.J., Puskaric, S., and van der Zwaan, J., 1992. Microhabitat selection by benthic foraminifera in the northern Adriatic Sea, J. Foraminiferal Res., 22, 297-317.

Benson, R.H. and Rakic-El Bied, K., 1991. The Messinian parastratotype ata Cuevas del Almanzora, Vera Basin, SE Spain: Refutation of the deep basin, shallow-water hypothesis? Micropaleontology, 37, 289-302.

Benson, R.H., Rakic-El Bied, K., and Bonaduce, G., 1991. An important current reversal (influx) in the Rifian Corridor (Morroco) at the Tortonian-Messinian boundary: the end of the Tethys ocean. Paleoceanography, v. $6(1), 164-172$. 
Bremer, M.L., Briskin, M., and Berggren, W.A., 1980. Quantitative paleobathymetry and paleoecology of the Late Pliocene-Early Pelistocene foraminifera of Le Castella (Calabria, Italia), J. Foram. Res., 10, 1-30.

Brunner, C.A., and Culver, S.J., 1992. Quaternary foraminifera from the walls of Wilmington, South Wilmington, and North Heyes Canyon, U.S. East Coast: implications for continental slope and rise evolution, Palaios, 7,34-66.

Buzas, M.A. and Gibson, T.G., 1969. Species diversity: benthonic foraminifera in western North Atlantic. Science, $163,72-75$.

Caralp, M.H., 1989. Abundance of Bulimina exilis and Melonis barleeanum: Relationship to the quality of marine organic matter, Geo-Marine Letters, 9, 37-43.

Cimerman, F., and Langer, M., 1991. Mediterranean Foaraminifera. Slovenska Akademija Znanosti in Umetnosti, Academia Scientiarum Artium Slovenica, Ljubliana, Classis IV, Historia Naturalia, 30, 118p.

Cita, M.B., 1976. Biodynamic effects of the Messinian Salinity Crisis on the evolution of planktonic foraminifers in the Mediterranean, Palaeogeogr., Palaeoclimatol., Palaeoecol. 20, 23-42.

De Stigter, H.C., Jorissen, F.J., and van der Zwaan, G.J., 1998. bathymetric distribution and microhabitat partitioning of live (Rose Bengal stained) benthic foraminifera along a shelf to deep sea transect in the southern Adriatic Sea, Journal of Foraminiferal Research,28, 40-65.

Ferretti, S. and Terzi, C., 1995. Late Miocene isotope stratigraphy and astronomical calibration of the Monte del Casino section (northern Apennines, Italy), G. Geol. Ser 3a. 57, 12, 99-112.

Fisher, R.A., Corbet, A.S., and Williams, C.B., 1943. The relationship between the number of species and the number of individuals in a random sample of an animal population, J. Anim. Ecol., 12, 42-58.

Glacon, G., Vergnaud-Grazzini, C., laccarino, S., Rehault, J.P., Randrianasolo, A., Sierro, F.J., and Weaver, P., 1990. Planktonic foraminiferal events and stable isotopic record in the Upper Miocene of the Tyrrhenian Sea, ODP Site 654, Leg 107. Proc. ODP Sci. Res. 107, 415-427.

Gooday, A.J., 1993. Deep-sea benthic foraminiferal species which exploit phytodetritus: Characteristic features and controls on distribution, Mar. Micropaleontol., 22, 187-205.

Hilgen, F.J., and Krijgsman, W., 1999. Cyclostratigraphy and astrochronology of the Tripoli diatomite Formation (pre-evaporite Messinian, Sicily, Italy), Terra Nova 11, 16-22.

Hilgen, F.J., Krijgsman, W., Langereis, C.G., Lourens, L.J, Santarelli, A., and Zachariasse, W.J ,1995. Extending the astronomical (pularity) time scale into the Miocene, Earth Planetary Science Letters, 136, 495-510.

Hodell, D.A., Benson, R.H., Kent, D.V., Boersma, A., and Rakic-El Bied, K., 1994. Magnetostratigraphic, biostratigraphic and stable isotope stratigraphy of an Upper Miocene drill core from the Sale Briqueterie (northwest Morocco): A high resolution chronology for the Messinian stage, Paleoceanography, 9, 835-855.

laccarino, S., 1985. Mediterranean Miocene and Pliocene Planktic foraminifera. In: Bolli, H.M., Saunders, J.B., Perch-Nielsen, K. (Eds.), Plankton Stratigraphy, Cambridge University Press, 283-314.

Jonkers, H.A., 1984. Pliocene benthonic foraminifera from homogeneous and laminated marls on Crete, Utrecht Micropal. Bull., 31, $179 \mathrm{pp}$.

Jorissen, F.J., 1987. The distribution of benthic foraminifera in the Adriatic Sea, Mar. Micropal., 12(1), 21-48.

Jorissen, F.J., 1999. Bentic foraminiferal microhabitats below the sediment-water interface, In Sen Gupta, B.K. (ed.), Modern Foraminifera, Kluwer, 161-179.

Jorissen, F.J., Barmawidjaja, D.M., Jorissen, F.J., Puskaric, S., and van der Zwaan, G.J., 1992. Vertical distribution of benthic foraminifera in the northern Adriatic sea: the relation with the organic flux, Mar. Micropaleontol. 19, 131-146.

Jorissen, F.J., 1987. The distribution of benthic foraminifera in the Adriatic Sea, Mar. Micropal., 12(1), 21-48.

Jorissen, F.J., 1999. Bentic foraminiferal microhabitats below the sediment-water interface, In Sen Gupta, B.K. (ed.), Modern Foraminifera, Kluwer, 161-179.

Jorissen, F.J., De Stigter, H.C., and Widmark, J.G.V., 1995. A conceptual model explaining benthic foraminiferal microhabitats, Mar. Micropaleontol., 26, 3-15.

Kaiho, K., 1994. Benthic foraminiferal dissolved oxygen index and dissolved oxygen levels in the modern ocean, Geology, 22, 719-722.

Katz, M.E., and Thunnell, R.C., 1984. Benthic foraminiferal biofacies associated with Middle Miocene to Early Pliocene oxygen-deficient conditions in the eastern Mediterranean, Journal of Foraminiferal Research, 14, 187-202.

Kouwenhoven, T.J., Seidenkrantz, M-S., and van der Zwaan, G.J., 1999. Deep-water changes: The nearsynchronous disappearance of a group of benthic foraminifera from the late Miocene Mediterranean, Paleogeography paleoclimatology paleoecology, 152, 259-281.

Krijgsman, W., Hilgen, F.J., Raffi, I., Sierro, F.J., and Wilson, D.S., 1999. Chronology, causes and progression of the Messinian salinity crisis, Nature 400, 652-655.

Krijgsman, W., Hilgen, F.J., Raffi, I., Sierro, F.J., and Wilson, D.S., 1999. Chronology, causes and progression of the Messinian salinity crisis, Nature 400, 652-655. 
Loubère, P., 1996. The surface ocean productivity and bottom water oxygen signals in deep-water benthic foraminiferal assemblages, Mar. Micropaleontol., 28, 247-261.

Loubère, P., 1997. Benthic foraminiferal assemblage formation, organic carbon flux and oxygen concentrations on the outer continental shelf and slope, J. Foram. Res., 27, 93-100.

Mullineaux, L.S., and Lohmann, G.P. 1981. Late Quaternary stagnations and recirculations of the eastern Mediterranean: changes in the deep water recorded by fossil benthic foraminifera, J. Foram. Res., 11, 20-39.

Murray, J.W., 1991. Ecology and paleoecology of Benthonic Foraminifera, Longman Scientific and Thechnical, London, 1-274.

Parker, F.L., 1958. Eastern Mediterranean Foraminifera. Reports of the Swedish deep-sea Expedition 19471948, vol. VIII. Sediment Cores and the Red Sea, 4, 283pp.

Pérez-Folgado, M., Sierro, F.J., Bárcena, M.A., Flores, J.A., Vázquez, A., Utrilla, R., Hilgen, F.J., Krijgsman, W., and Filipelli, G.M., 2003. Western versus eastern Mediterranean paleoceanographic response to astronomical forcing: a high-resolution microplankton study of precession-controlled sedimentary cycles during the Messinian, Paleogeogr. Paleoclimatol. Paleoecol. 190, 317-334.

Phleger, F.B., and Soutar, A., 1973. Production of benthic foraminifera in three east Pacific oxygen minima, Micropaleontology, 19, 110-115.

Rohling, E.J., and Bigg, G.R., 1998. Paleosalinity and $\delta^{18} \mathrm{O}$ : a critical assessment, J. Geophys. Res., C: Oceans, 103, 1307-1318.

Rohling, E.J., De Stigter, H.C., Vergnaud-Grazzini, C., and Zaalberg, R., 1993. Temporary repopulation by lowoxygen tolerant benthic foraminifera within an upper Pliocene sapropel: Evidence for the role of oxygen depletion in the formation of sapropels, Mar. Micropaleont., 22, 207-219.

Seidenkrantz, M.S., Kouwenhoven, T.J., Jorissen, F.J., Shackleton, N.J., and van der Zwaan, G.J., 2000. Benthic foraminifera as indicators of changing Mediterranean-Atlantic water exchange in the late Miocene, Mar. Geol., 163, 387-407.

Shackleton, N.J., Crowhurst, S., Hagelberg, T., Pisias, N.G., and Schneider, D.A., 1995. A new late Neogene time scale: Application to Leg 138 sites, Proc. ODP Sci. Res. 138, 517-533.

Sierro, F.J., Flores, J.A., Bárcena, M.A., Vázquez, A., Utrilla, R., and Zamarreno, I., 2003. Orbitally-controlled oscillations in the planktic communities and cyclical changes in western Mediterranean hydrography during the Messinian, Palaeogr. Palaeoclimatol. Palaeoecol., Soo31-0182(02)00611-9.

Sierro, F.J., Hilgen, F.J., Kiijgsman, W., and Flores, J.A., 2001. The Abad composite (SE Spain): A Mediterranean and global reference section for the Messinian, Palaeogeogr. Palaeoclimatol. Palaeoecol. 168, 141169.

Sprovieri, R., Di Stefano, E., Caruso, A., Bonomo, S., 1996. high resolution stratigraphy in the Messinian Tripoli Formation in Sicily, Palaeopelagos 6, 415-435.

Todd, R., 1957. Smaller foraminifers. In Geology of Saipan, Mariana Islands (Pt. 3), Paleontology. Geol. Surv. Prof. Pap. U.S., 280-H, 265-320.

Triantaphyllou, M.V., Tsaparas, N., Stamatakis, M., and Dermitzakis, M.D., 1999. Calcareous nannofossil biostratigraphy and petrological analysis of the pre-evaporitic diatomaceous sediments from Gavdos Island, southern Greece. Neues Jahrb. Geol. Paläontol. Mon.heft 3, 161-178.

Van der Zwaan, G.J., 1982. Paleoecology of Late Miocene foraminifera, Utrecht Micropal. Bull., 25, 1-201.

Van der Zwaan, G.J., and Den Hartog Jager, D., 1983. Paleoecology of Late Miocene Sicilian benthic foraminifera, Proc. Kon. Ned. Acad. Wetensch., Ser. B 86, 211-223.

Van der Zwaan, G.J., and Jorissen, F.J., 1991. Biofacial patterns in river-induced shelf anoxia. In: R.V. Tyson \& T.H. Pearson (Eds), Modern and Ancient Continental Shelf Anoxia, Geol. Soc. Spec. Publ., 58, 65-82.

Van der Zwaan, G.J., Duijnstee, I.A.P., Den Dulk, M., Ernst, S.R., Jannink, N.T., and Kouwenhoven, T.J., 1999. benthic foraminifers:proxies or problems? A review of paleoecological concepts, Earth Science Reviews, 46 (1-4), 213-235.

Van der Zwaan, G.J., Jorissen, F.J., and de Stigter, H.C., 1990. The depth dependency of planktonic/benthic foraminiferal ratios: Constraits and applications, Marine Geology, 95, 1-16.

Van Morkhoven, F.P.C.M., Berggren, W.A., and Edwards, A.S., 1986. Cenozoic cosmopolitan deep-water benthic foraminfera, Bulletin des Centres de Recherches Exploration-production Elf-Aquitaine, Memoir, 11 , $421 \mathrm{p}$.

Venec-Peyre, M.T., 1984. Etude de la distribution des foraminiferes vivant dans la baie de Banyuls-sur-Mer. In Association Francaise des Techniciens dy Petrole "ECOMED ", 60-80.

Vergnaud-Grazzini, C., 1983. Reconstruction of Mediterranean Late Cenozoic hydrography by means of carbon isotope analysis, Utrecht Micropaleontol. Bull. 30, 25-47.

Verhallen, P.J.J.M., 1991. Late Pliocene to early Pleistocene Mediterranean mud-dwelling foraminifera ; influence of a changing environment on community structure and evolution, Utrecht Micropaleontol. Bull., 40, $219 \mathrm{pp}$. 